\title{
Variety of Regional Innovation Systems and their Institutional Characteristics
}

\begin{abstract}
Regional Innovation Systems (RISs) come in many shapes. Current RIS typologies, however, pay insufficient attention to institutional factors and as a consequence they fall short of capturing an essential source of variety of RISs in a systematic way. This chapter contributes to a further conceptual development of the RIS approach by capturing regional variety not only in terms of actors and networks but also in terms of institutions. It is shown that an institutional perspective can enrich existing RIS typologies by providing insights into the distinctive institutional frameworks of different RIS types and their particular institutional bottlenecks. Three main causes of institutional bottlenecks are identified, that is, lack of or poorly developed institutions, inappropriate institutions, and contradicting/poorly aligned institutions. As shown in this chapter the institutional perspective advocated here holds a strong potential to contribute to a further conceptual development of the RIS approach.
\end{abstract}

Keywords: Institutions, Institutional bottlenecks, Types of Regional Innovation Systems

Elena Zukauskaite

School of Health and Welfare

Halmstad University

Kristian IV:s väg 3

S-301 18 Halmstad, Sweden

elena.zukauskaite@hh.se 


\section{Introduction}

There seems to be a widespread agreement in the academic literature that any definition of regional innovation systems (RISs) is incomplete without reference to institutions. The claim that institutions matter can already be found in the antecedents of the RIS approach, that is, i) the national innovation system (NIS) concept (see, for instance, Johnson's (2010) analysis of the role of institutions in innovation processes) and ii) various territorial innovation models. The latter have highlighted the significance of the regional socio-institutional environment from which innovations emerge (Doloreux and Parto, 2005). The key argument advanced in this literature is that uncertainty is increasing in the globalizing knowledge economy. Therefore, competitive advantage can be preserved by possessing some unique assets that cannot be easily copied (like traditions, values), and by creating patterns of behaviour that facilitate and enable fast responses to changing environments (Storper and Scott, 1995; Storper, 1997; Porter, 1998; Bathelt, Malmberg and Maskell, 2004).

However, a closer look clearly reveals that the elaboration of the term 'institution' is rather limited in the RIS literature (see Zukauskaite (2013) for a comprehensive critical appraisal of the use of the notion in the RIS debate). Institutions are usually defined either as an infrastructure in the form of research and funding organizations and technology transfer agencies or as historically formed conditions related to regional traditions or path-dependency (Asheim and Isaksen, 1997; Cooke, 2004; Iammarino, 2005). Various authors have emphasized that due attention should be given to the relation between institutions and knowledge exchange (see for instance, Cooke, Uranga and Etxebarria, 1997; Asheim and Gertler, 2005). Innovation linkages between RIS actors are seen as vital for a well-functioning innovation system. A huge literature does exist that portrays innovation as an interactive and systemic phenomenon, that is, as the outcome of cooperation between firms or between firms and research organizations. It is argued that such interactions are influenced and shaped by the regional institutional framework. Regions are considered as organizing units bringing together the infrastructure needed for innovative activities (Florida, Adler, and Mellander, 2016). Physical proximity at the region level (sometimes also seen as a proxy for cultural proximity; see, for instance, Gertler (2004)), implies the existence of trust, which is considered as a basic precondition for collaboration and knowledge exchange. In addition to trust, network creation and collaboration are facilitated by democratic participation in the regional life. Civic institutions and communal spirit within the region could lead to knowledge exchange among different actors, which in turn benefits innovation activities and economic development (Amin and Thrift, 1995; Scott, 1998).

RISs are conceptualized as open, nationally and internationally connected systems. This directs our attention to institutions at higher spatial scales. Already Martin (1994) argued that regions are the places where different kinds of institutions - national, regional, global and organizational ones - interact. That is, the regional institutional framework includes national and global regulations as well as industry specific laws, standards and routines (Asheim, Smith, and Oughton, 2011a). This idea is further supported by Farole, Rodriguez-Pose, and Storper (2011) who have convincingly argued that both formal and informal institutions need to be considered in RIS analyses. However, regardless the re-occurring calls to account for the 
institutional diversity in the region, it is hardly conceptualized and empirically analyzed in RIS studies (Gertler, 2010).

As will be shown below, the lack of an adequate conceptualization of institutions is also reflected in various typologies that have been developed to capture the variety of RISs. Variety is usually conceptualized and empirically analyzed in terms of actors involved and types of networking. In other words, actors and networks are the main dimensions that are used to describe and analyze different types of RISs. However, if institutions are crucial for regional development and innovation, as the protagonists of the concept repeatedly claim, RISs might also differ in their institutional characteristics. Current RIS typologies, however, pay insufficient attention to the institutional dimension and as a consequence they fall short of grasping institutional sources of variety of RISs in a systematic way.

The aim of this chapter is to shed light on the formal and informal institutional characteristics of different types of RISs. This chapter does not develop a new typology of RISs, but rather analyzes existing ones from an institutional perspective, seeking to make regulative, normative and cognitive aspects of the RIS approach more explicit and prominent. We provide profound insights into the distinctive institutional framework of different types of RISs and we identify particular institutional bottlenecks that can be found in each of these types. It is argued that such an institutional analysis has the potential to further advance our conceptual understanding of RISs and enhance our knowledge of the institutions of various RIS types.

The remainder of this chapter is structured as follows. Section 2 offers a conceptualization of institutions that is in line with recent advances in the field. Section 3 provides a critical analysis of various RIS typologies, highlighting the ways in which they grasp variety of RISs as well as how (if at all) institutional characteristics are discussed. In Section 4 institutions are incorporated into typologies of RISs. Finally, Section 5 concludes.

\section{Conceptualizing Institutions}

Conceptualizations of institutions in economic geography and the innovation systems literature have been inspired by many disciplines and school of thoughts. Old (Veblen, 1898; Hodgson, 1998) and new (North, 1990; Williamson, 2000) institutional economics are certainly among the most influential ones, but increasingly insights from other disciplines are incorporated into the geographical analysis of institutions. In particular, the new institutionalism in organizational studies, historical institutionalism and social psychology are worth mentioning in this regard (see, for example, Gertler and Wolfe, 2002; Gertler, 2004, 2010).

As indicated above, RIS studies tend to refer to universities, schools, banks and policy support organizations as institutional infrastructure of the region often with no explicit consideration about the relation between organizations and institutions (see Farole, Rodriguez-Pose, and Storper, 2011; Bathelt and Glückler, 2014 for a discussion). However, in order to 
conceptualize institutions in different types of RISs, there is a need to distinguish between the two phenomena. Following North (1990), institutions are understood as formal and informal rules such as regulations, values and routines while organizations such as universities, banks, schools, policy organizations, and firms are actors that follow, disobey or initiate the rules.

This idea is further supported by Scott (2008) who argues that institutions comprise regulative (regulations), normative (norms) and cultural-cognitive (beliefs) elements that structure (enable and constrain) the behavior of individuals and organizations. The regulative element of institutions refers to rules, laws, sanctions, which are legally enforced. This type of institutions is usually codified in laws, standards, agreements (such as intellectual property rights), taxation policies and labor relations. Such institutions also include different guidelines that regulate various types of support (that is, funding and infrastructural support for science, technology, innovation, regional development, and so on) (see also North, 1990; Williamson, 2000). As discussed above, regulative institutions are often found at the national level (such as national laws) and the global one (like industry standards, EU regulations) (see Edquist, 2005; Cooke and Propris, 2011). In regions with high levels of political autonomy, that is, in federal states with a considerable degree of decentralization of power, some of the regulative institutions discussed above can also be found at the sub-national level (see Table 1).

Normative institutions consist of values, social obligations and binding expectations, which are morally governed. They specify how things should be done and define appropriate ways to reach goals or to organize certain activities. The cultural-cognitive aspect of institutions refers to the views of the world, which are taken for granted. They are based on shared understandings and logic of action and mimetic behavior (Scott, 2008). Cognitive and normative institutions are facilitated by geographical proximity and are therefore often specific to certain regions. However, there might also be norms and beliefs that are specific to industries or communities of practice. They often exceed the regional level and are related to other types of proximity than geographical one (Boschma, 2005). For example, academic communities across different countries share some underlying understanding what high quality research is and follow established ways (i.e. peer-review process) to achieve it.

Normative and cultural-cognitive elements of institutions differ when it comes to their enforcement. Normative institutions are enforced via moral codes of conduct when deviation from the norm leads to moral shaming and social exclusion. Cultural-cognitive institutions are taken for granted (Scott, 2008). There is no need for special enforcement mechanisms since the alternative (that is deviation) cannot be explicitly considered by those subscribing to a particular cultural-cognitive institution. Having said that, it has to be acknowledged that the empirical distinction between normative and cultural-cognitive institutions is not always a clear-cut. It is contingent to time, place and community ${ }^{\mathrm{i}}$.

The types of institutions outlined above are not isolated, but experienced and enacted in an interrelated manner (Scott, 2010). Various scholars have highlighted that formal and informal institutions are mutually reinforcing. Without supporting normative and cultural-cognitive institutions, enforcement of regulations would be very costly (North, 1990; Scott, 2008). However, institutions can also be interrelated in a complementary or contradicting manner. 
For example, institutions that have the same goal (for instance, promotion of innovation) and the same function (for instance, providing funding structures for innovation) are reinforcing each other. Institutions that have the same goal but different functions (for instance, providing funding structures for innovation and encouraging positive attitudes towards innovation) are complementary. Institutions are related to each other in a contradictory manner if they have opposing goals (for instance, promotion of innovation versus preservation of historically formed structures and interests) (see, Zukauskaite (2013) for a more in-depth critical discussion of various forms of interrelationships between different institutions). Furthermore, it is important to note that regions are embedded in national and global environments and they usually host different industries and a heterogeneous population of firms and other organizations. This suggests that the institutional framework of the region can be very complex, leading to various kinds of relations between different kinds of institutions.

\section{Typologies of Regional Innovation Systems}

Regions differ from each other in many respects such as size, firm density, industrial specialization patterns, knowledge bases, presence of research and supporting organizations, political autonomy, aspects of governance and so on. In order to grasp this variety of regional characteristics different typologies of RISs have been developed over the past years.

In this section, we take a closer look on four typologies that figure prominently in the RIS literature to find out how they treat the institutional dimension of regional innovation processes. The typologies presented below have been selected for an analysis of institutions because they are amongst the most well-known ones and have been widely used by scholars working in the field of innovation systems ${ }^{\mathrm{ii}}$. We seek to explore to what extent and in what ways these typologies do consider various forms of institutions as they have been defined in Section 2. The findings of our analysis are summarized in Table 2.

\subsection{Territorially embedded, regionalized national and regional networked RISs}

One of the most detailed typologies was developed by Asheim and Coenen (2005). They distinguish between territorially embedded, regionally networked and regionalized national RISs. In many ways this typology resembles Cooke's (2004) distinction between localistgrassroots, globalized-dirigiste and interactive-networked RISs. According to Asheim and Coenen (2005), a territorially embedded RIS is characterized by the presence of inter-firm learning stimulated by the conjunction of geographical and relational proximity with almost no direct interaction with knowledge generation organizations. The regional support infrastructure provides industry specific, hands-on services and short-term problem solving. 
Furthermore, the nature of knowledge exchange and collective learning is primarily local, rarely transcending regional boundaries. Cooke (2004) adds that firms in such RISs usually use local funding sources for innovation and usually have strong links with regional policy makers.

In a regionalized national innovation system innovation is often organized in a linear mode where highly codified scientific knowledge is transferred to the industry for commercialization. Co-operation is most likely to arise between people with the same education or occupational background. This functional similarity facilitates the circulation and sharing of knowledge through epistemic communities crossing regional and even national boundaries. Funding for innovation comes from national or global levels. The global dimension of this RIS type is further highlighted by Cooke (2004) who argues that the industrial structure of such RISs is dominated by global multinational companies surrounded by local suppliers. Research activities are geared towards the needs of MNEs and might be performed in global collaboration with the research organizations around the world.

Finally, a regionally networked RIS is considered an ideal type of RISs involving private and public cooperation of a planned character. It has a balanced private sector including small and large firms in different sectors. Knowledge exchange can vary from the local level, to regional, national and global ones, depending on the needs and goals. The research competence in such systems ranges from basic to applied research and meets the demands of a variety of different types of firms. Cooke (2004) points out that system co-ordination is likely to be high because of the large number of stakeholders and the presence of associations, industry clubs and the like. Funding of innovation activities is guided by agreements among banks, government agencies and firms.

The typologies presented above thus attempt to identify various kinds of RISs by focusing attention on three distinguishing features, that is, actor constellations (small versus large firms), type of innovation processes (experience based (DUI) versus science based (STI)) and collaboration patterns (within or outside the region, private-private actors, private-public actors), leaving the concept of institutions implicit to the framework. However, some of the RIS characteristics highlighted above could be related to institutions. Different types of networks such as links between SMEs in territorially embedded RISs or connections within epistemic communities in regionalized national innovation systems could possibly point to varying normative and cultural-cognitive institutions. Furthermore, geographical and relational proximity is mentioned when describing territorially embedded RISs which suggests presence of normative and cultural-cognitive institutions, supporting trust, knowledge exchange and encouraging mimetic behavior. In the empirical application of the typology, Asheim and Coenen (2005) mention that joint norms, conventions, and routines are of crucial importance for interactive learning among the firms in territorially embedded RISs. Reference to collaborations transcending regional boundaries in regionalized national innovation system and networked regional innovation systems imply a significant role of regulative institutions at national and global levels. Furthermore, the reference to knowledge sharing in epistemic communities in regionalized national innovation systems indicates the presence of normative and cultural-cognitive institutions crossing different geographical 
levels. However, these institutional aspects remain implicit in the typologies. They hint to possible institutional variety in different types of RISs, but further elaborations are missing.

\subsection{Entrepreneurial and institutional RISs}

Another typology suggested by Cooke (2004) differentiates between institutional RISs (IRISs) and entrepreneurial IRSs (ERISs). IRISs are characterized by strong user-producer interactions, supporting regulatory frameworks such as public investment in research (laboratories and universities), and a dependence on bank borrowing (patient capital) leading more often to incremental rather than radical innovations. ERISs lack these strong systemic elements and instead get their dynamism from local venture capital, entrepreneurs, and market demand. They are well suited to generate both incremental and disruptive innovation. Since the dynamism comes from venture capitalists, the driving force is a more short-term profit boosting of shareholders rather than the more long-term perspectives of a broader group of stakeholders in an IRIS context (see also Cooke, 2001; Asheim and Coenen, 2006). These two types of RISs, thus, reflect the varieties of the capitalism dichotomy of coordinated and liberal market economies (Asheim and Coenen, 2006; Asheim, 2007).

In this dichotomy, institutions are mentioned in a very limited manner. Cooke's (2004) IRISERIS typology does hardly go beyond a brief recognition of possibly different norms governing the actors (shareholders' profit making versus long term interests of shareholders) and the importance of public investment in research in IRISs. Regulative institutions that govern ERISs, such as low taxes and weak labor unions, which are typical characteristics of liberal market economies, are not mentioned at all ${ }^{\mathrm{iii}}$.

\subsection{Organizationally thin, locked-in and fragmented RISs}

Tödtling and Trippl (2005) differentiate among RISs based on their potential innovation deficiencies. They identify three types of RIS failures (organizational thinness, lock-in and fragmentation) and assign them to specific types of regions. Similar to other typologies, variety is conceptualized in terms of actors, networks and activities. Organizationally thin RISs (often found in peripheral regions) feature low levels of clustering, SMEs with limited innovation capabilities operating in mature sectors and a weak endowment with supporting organizations. Due to the low number of innovative players in the region, extra-regional innovation networks tend to be more pronounced than intra-regional ones. Locked-in RISs (usually found in old industrial areas), in contrast, are characterized by organizational thickness. They host, strong clusters that are, however, overspecialized in old industries undergoing decline, a support structure that is too strongly oriented to the region's narrow industrial base and outdated technologies. More often than not, too strong economic and political ties suppress novel ideas and new economic activities. Finally, fragmented RISs (often found in metropolitan areas) are portrayed as systems that suffer from low levels of networking and knowledge flows between the large number of RIS actors (firms, research and 
educational bodies and supporting organizations) present in the area. Such connectivity problems might result from too much industrial and knowledge diversity (lack of synergies) or from networking barriers that prevent actors to capitalize on synergies.

Tödtling and Trippl (2005) do not offer a systematic account of the role of institutions in different types of RISs. Institutions are mentioned in the authors' description of locked-in RISs, which are characterized by functional lock-ins (too rigid inter-firm networks), cognitive lock-ins (homogenization of world views), and political lock-ins (strong, symbiotic relationships between public and private key actors hampering industrial restructuring). This could be further related to normative and cultural-cognitive institutions. Old industrial regions and their locked-in RISs have clearly established views on what legitimate and appropriate ways of organizing activities and networks are and serious questioning is applied when anyone deviates from established norms. Furthermore, a long history of a particular industrial structure leads to mimetic behavior among the actors, when a certain pattern of actions is copied by others and over time becomes taken-for-granted. Thus, homogenous culturalcognitive institutions tend to prevail in these areas. According to the authors, peripheral regions are characterized by a 'thin institutional structure' (Tödtling and Trippl, 2005: 1209). The authors do not elaborate on what is meant by that. However, it can be interpreted as the lack of institutions supporting knowledge exchange and networking, partly due to the lack of a critical mass of actors who could enact such institutions (Amin and Thrift, 1995). Finally, for fragmented RISs institutions are not mentioned at all.

To summarize, our critical analysis of various well-known RIS typologies has clearly shown that they underappreciate institutional factors in their attempts to identify and categorize various kinds of RISs. In the next section, we highlight how an institutional perspective can enrich these typologies.

\section{RISs Typologies and Institutions}

As mentioned above, this chapter does not aim to develop a new typology of RISs, but rather seeks to grasp institutional variety within existing typologies. These typologies are developed with different purposes in mind and therefore institutional characteristics have to be defined along different dimensions. Asheim and Coenen's (2005) typology highlights the nature of the relations among actors. Thus, due attention is given to the relative importance of institutions at various geographical levels. Tödtling and Trippl's (2005) typology captures the main RIS deficiencies. Consequently, the main focus is on institutions that could lie behind or could add to the solution of the deficiency. Finally, Cooke (2004) describes IRISs and ERISs in relation to their ability to nurture different types of industries. Institutions that go in line with that ability are pointed out. By adding key institutional features to the typologies of RISs, we gain an additional explanatory dimension (apart from actors and networks) for a better understanding of relations among actors, regional deficiencies, and conditions for the development of different industries (see Table 3). In this way, the conceptual analysis developed in this chapter provides further insights into how institutional frameworks of the 
region and institutional bottlenecks shape innovation activities and types of innovation that dominate different RISs.

4.1 Institutional features and bottlenecks of territorially embedded, regionalized national and regionally networked RISs

Normative and cultural-cognitive institutions among actors at the regional level are most influential in territorially embedded/localist-grassroots RISs. This is an outcome of the mimetic behavior of actors located in the region since non-local interactions are limited. Welldeveloped relations between local policy makers and local firms together with the lack of supra-local coordination suggest an inward orientation of the system. National and global regulative institutions are only important as providers of basic regulations such as labor and taxation policy, industry standards and intellectual property rights. Institutions that facilitate and encourage supra-regional interaction could hardly become a part of the institutional framework of the region. This is due to the preference for regional collaboration partners over distant ones and a dominant belief in established local practices. Thus, the main institutional bottleneck is a lack of institutions in the region that could promote supra-regional collaboration and interaction. Even in those cases when such institutions exist at national or global levels, there is a risk that they are disregarded by the regional actors and thus do not feed into the institutional framework of the region. This would also imply that there is a lack of interrelatedness among institutions at different geographical scales due to the superiority of the regional level. Supply-side policies such as funds supporting supra-regional collaboration will not be enough to overcome institutional bottlenecks as they object the dominant worldview of RIS actors.

Normative institutions come into being only if actors perceive certain norms and codes of conduct as beneficial to their performance and/or can be regarded as fair (Hall, 2010). In order to support the change of norms towards more openness, regional policy makers can provide good practice examples from the same or other regions and use opinion leaders to persuade other actors. Close relations between SMEs and policy makers might create both opportunities for and constraints to such actions. On the one hand, it means that policy makers have easy access to the companies and possibilities to exert an influence on them. On the other hand, they might subscribe to the same normative and cultural-cognitive institutions and therefore do not realize the need for change.

Due to the national/global focus of regionalized national/globalized-dirigiste RISs regional institutions for collaboration across industries or organizational fields are poorly developed. The most influential ones are national institutions predefining support and incentives structures for innovation and industry practices. However, due to the functional focus of the actors cultural-cognitive and normative institutions of the epistemic community are also important for innovation and apply both to regional and supra-regional (global) levels. The relation between institutions is mainly complementary when the norms of epistemic communities supporting intra-industry interaction are complemented by support structures at the national level. There is a vast literature on related variety, constructing regional 
advantage, Triple Helix (among others) suggesting that collaboration across industries and organizational fields is more conducive to innovation and regional development than a single industry focus (Etzkowitz and Leydesdorff, 1997; Asheim et al., 2007; Asheim, Boschma and Cooke, 2011b). Thus, weak regional institutions for collaboration across industries/organizational fields are the main institutional bottlenecks of the system. Changes in epistemic communities might be important triggers for change. For example, crossdisciplinary collaboration in the field of functional genomics in southern Sweden was triggered by changes of norms in the epistemic community regarding what good quality research is about (see Zukauskaite (2015). If such change does happen, it is important that policy makers adjust their support for the industry and allow for further upgrading.

Regionally networked/interactive-networked RISs are often considered an ideal type of RISs. We expect institutions at all levels to be important for supporting knowledge exchange and innovation. Normative institutions that support knowledge exchange and learning at the regional level are further reinforced by national incentives and complemented by regulations and support structures at national and global levels. Some empirical studies suggest that such RISs also have formal contracts (regulative institutions) for collaboration among regional actors (Hallencreutz, Bjerkesjö and Daal, 2008). Actors within regionally networked RISs have well-developed networks for global collaborations. Thus, global regulative institutions such as agreements, standards and intellectual property rights are crucial for the functioning of the RIS. However, regional actors might have a limited influence on global institutions. Thus, institutional bottlenecks might emerge due to the lack of, for example, industry standards or unfavorable labor and tax policies in countries where the preferred partners of RIS actors are located. Regional policy makers can hardly change institutions at other geographical levels, but they can lobby at international (EU) and national levels for the interest of actors in the region. Furthermore, they can also provide information about regulative challenges and in such a way reduce regulatory burdens (Miörner et al., 2016).

\subsection{Institutional features and bottlenecks of entrepreneurial and institutional RISs}

As suggested by Cooke (2004) normative institutions at regional and national levels in IRISs promote long-term interest and trust among stakeholders, encouraging collaboration among different actors. Due to low labor mobility, there is a high level of loyalty among employees and employers. This stands in stark contrast to ERISs where the level of loyalty among employees and employers is low and normative institutions encourage a focus on short-term profit making and market demand.

Cooke's (2004) typology of ERISs and IRISs reflects Hall and Soskice's (2001) concept of varieties of capitalism where specialization of the national economy is predefined by historically formed national institutional frameworks (Asheim and Coenen, 2006; Asheim, 2007). It would mean that the regions in Coordinated Market Economies (CMEs) are more likely to resemble IRISs whilst those in Liberal Market Economies (LMEs) resemble ERISs. Thus, in IRISs typical characteristics of regulative institutions at the national level are strict labor regulations, influential labor unions and other industry organizations, facilitating inter- 
organizational coordination, high taxes, and a focus on strong vocational training in the education system. In ERISs labor regulations are fluid, taxes are low, labor unions usually weak and the education system is focused on broad, general knowledge. Thus, the relation between institutions is mainly complementary. Low loyalty between employees and employers and a focus on profit and market demand (normative institutions) are complemented by fluid labor regulations (Hall and Soskice, 2001). However, if the national environment does not support competitiveness of the firms (CMEs, for example, are generally considered as less favorable settings for 'high-tech' industries such as biotech than LMEs), the regional environment might deviate from national models to support certain industries located there (Crouch, Schroder, and Voelzkow, 2009). Strambach (2010) noted that industries can emerge despite an environment that is unfavorable for their development, pointing to the plasticity of institutional frameworks. Thus, it might be possible to find IRISlike institutions in regions located in LMEs and ERIS-like institutions in CMEs suggesting partly contradicting relations between institutions at the national and regional levels. This points to institutional bottlenecks when the industry cannot achieve its full potential due to the regulations at the national level. Similarly, as with networked-RISs, the influence of regional policy makers on overcoming such institutional bottlenecks is rather limited. Lobbying at the national level in order to achieve better conditions for the industry in the region, providing information about regulatory frameworks, and continuous support of favorable institutions at the regional level are possible tools that can be used by policy makers.

Because of the national focus in capturing variety in ERISs and IRISs, it is hard to distinguish the role of global institutions. Both CMEs and LMEs (and thus both ERISs and IRISs) are subject to the same global institutional settings. ERISs are considered more beneficial for science-based industries such as biotechnology, while IRISs are better suited for engineering based industries such automotive. Some recent studies reveal that science-based industries are much more involved in global collaboration and knowledge exchange than engineering-based industries (see, for instance, Martin and Moodysson, 2013). Thus, one could expect that global cooperation agreements, industry standards and incentive structures for collaboration are more relevant for actors in ERISs than in IRISs.

4.3 Institutional features and bottlenecks in organizationally thin, locked-in and fragmented RISs

Locked-in RISs are characterized by thick cognitive and normative institutions, which have emerged over time through mimetic behavior of organizations located in the region. They lead to shared understandings among the actors and predefine legitimate forms of behavior and activities. Alternative attitudes that are not in line with established norms and culturalcognitive beliefs are questioned and often rejected (see, for example, the studies done by Grabher (1993) and Hassink (2010) on old industrial regions). Regulative institutions at the 
national and global level such as industry standards, regulations regarding work relations and practices are usually well-developed and in place. When it comes to support structures for industrial development (such regions are often dominated by one industry or a few closely related ones) there are several institutional alternatives. They might be well-developed and in line with the understanding of the regional actors of how the industry should develop. The support structures can be dismantled if the industry dominating in the region is declining and thus, not prioritized any longer by policy makers. Finally, support structures at national and global levels might aim to promote industry renewal. However, RIS actors might be unwilling and/or incapable to absorb such support since it is not in line with the normative and culturalcognitive institutions that prevail in the region. Thus, the relations between institutions might be complementary, reinforcing or contradicting. 'Thick' institutions that encourage traditional ways of organizing activities and hamper regional and industrial renewal form the main institutional bottlenecks in these areas. Similar to territorially embedded RISs, regional policy makers can use good practice examples and act via opinion leaders in order to overcome institutional lock-in.

In organizationally thin RISs there is a lack of a critical mass of actors for promoting regional development. According to Amin and Thrift (1994) this hampers the development of normative and cultural-cognitive institutions at the regional level (see also Zukauskaite, Trippl, and Plechero (2017) for a discussion on institutional and organizational thickness/thinness). Thus, one could expect such a RIS to be not only organizationally but also institutionally thin. Nevertheless, mimetic behavior and shared world views are likely to emerge among relatively small group of actors. This might lead the establishment of a normative and cultural-cognitive institutional framework representing values and beliefs characteristic to the region. This idea is supported by Trippl, Asheim, and Miörner (2016) who define industrial districts in the Third Italy as organizationally thin, but institutionally thick due to normative and cultural cognitive institutions supporting collaboration shared by the majority of actors. Normative and cultural cognitive institutional framework is expected to be homogeneous in these types of regions. However, it is still thin since there are only few actors who comply with the framework.

Most relevant regulative institutions at national and global levels are those that address the issue of less developed regions, that is, taxation policy, support structures, and so on. The lack of such institutions might further reinforce the weak innovation capacity of organizationally thin RISs. Since such RISs are institutionally thin, the relation between institutions is less important for regional development. Regional policy makers can address the problem of 'lack of critical mass of actors' by enlarging the region via, for example, improved transport infrastructure and collaboration agreements with neighboring regions. If support structures for less-developed regions are missing at the national level, policy makers can lobby for and actively apply them once they are in place. Once the region reaches a critical mass of actors, it has the possibility to develop institutions that support innovation and knowledge exchange since it is less bounded by historically formed traditions than for example, locked-in regions.

Fragmented RISs are typical for metropolitan regions that host a large number of actors with competing agendas. This leads to a variety of different norms and beliefs and varying levels 
of trust among the actors. Similarly, there is a variety of different regulations. For some industries and cooperation forms rules and support structures might be well-established, while for others regulations might be missing. Since the main deficiency of such RISs is fragmentation, the most relevant institutions at national and global levels are those that facilitate collaboration among different stakeholders. Missing or poorly developed institutions encouraging collaboration and knowledge exchange at various levels form the main institutional bottleneck. Furthermore, due to the variety of norms and regulations in the region, the relations are very complex. Complementary, reinforcing and contradicting institutions might be in action simultaneously. For example, it might be the case that national support structures and norms of global epistemic communities promote collaboration (complementary relations), while regulations that are specific to industries or organizational fields make legitimization of collaboration activities very complicated (see Zukauskaite (2015) for a further elaboration of this argument). Thus, poorly aligned institutions might also lead to institutional bottlenecks in fragmented metropolitan RISs. Regional policy makers might actively identify such contradictions and raise awareness of the problem at different levels and organizational contexts. In case of negative attitudes towards collaboration, policy makers can use good examples as well as suggest formal contracts in order to overcome the lack of trust among diverse actors.

\section{Conclusions}

Over the past 20 years or so, the RIS concept has received much interest in economic geography and innovation studies. There is a strong consensus within the academic debate that institutions are key elements of RISs, shaping the innovation dynamics of regions in essential ways. Despite the widespread recognition of the influence of institutions, the notion is still weakly conceptualized in the literature on RISs. As shown in this chapter, the lack of a proper conceptualization of institutions is also reflected in various well-known RIS typologies. These typologies have without any doubts enhanced our understanding of how RISs differ in terms of key actors and networks, capacity to facilitate innovation in various kinds of industries, and prevailing innovation problems resulting from distinct system failures. However, RISs also vary significantly in their institutional characteristics. Based on a critical analysis of prominent RIS typologies we have demonstrated that this work has paid only limited attention to institutions and as a consequence institutional sources of variety of RISs remain poorly understood.

This chapter sought to enrich existing RIS typologies by identifying key institutional features that shape and constrain innovation activities in various kinds of RISs. Inspired by the work done by Scott (2008) and others we advanced the argument that such an undertaking requires a focus on different types of institutions (regulative, normative, cultural-cognitive) at various spatial scales (regional, national, global) and their interrelationships. This enabled us to provide deep insights into the distinctive institutional frameworks of different types of RISs and their particular institutional bottlenecks. We offered a fine-grained conceptual analysis of the role played by regulative, normative and cultural-cognitive institutions and their 
interscalar relations and we highlighted how a focus on the presence (or absence) of various kinds of institutions and the particular nature of their interrelationships which can be reinforcing, complementary or contradictory can help explain differentiated innovation capacities of regions. We have identified three main causes of institutional bottlenecks, that is, lack of or poorly developed institutions, inappropriate institutions, and contradicting/poorly aligned institutions.

As shown in this chapter the institutional perspective advocated here holds a strong potential to contribute to a further development of the RIS approach It can inform empirical studies of RISs and might also pave the way for fresh insights into the scope but also limitations of innovation policies adopted at the regional level. Furthermore, it can also add to further conceptual advances of the RIS concept. Not least it could contribute to a better understanding of regional change. As revealed by Isaksen and Trippl (2016) different types of regions are likely to support different types of development of regional industrial paths. Better understanding of institutional frameworks and how they enable or constrain new regional path development in different types of regions could further inform studies of regional structural change (see also Zukauskaite, Trippl, and Plechero, 2017).

\section{Acknowledgement}

This chapter has benefited a lot from Michaela Trippl's insightful comments. I am also grateful to Arne Isaksen and an anonymous reviewer for further suggestions on how to improve the chapter. Any remaining errors or shortcomings are my sole responsibility.

\section{References}

Amin A. and Thrift N. (1995). Institutional Issues for the European Regions: From Markets and Plans to Socioeconomics and Powers of Association. Economy and Society, 24(1), pp. 4166.

Asheim, B. (2007). Differentiated Knowledge Bases and Varieties of Regional Innovation Systems. Innovation. The European Journal of Social Sciences, 20(3), pp. 223-41.

Asheim, B. (1998). Learning Regions as Development Coalitions: Partnership as Governance in European Workfare States? Paper presented at the Second European Urban and Regional Studies Conference on 'Culture, place and space in contemporary Europe', University of Durham, UK.

Asheim B. and Coenen L. (2005). Knowledge Bases and Regional Innovation Systems: Comparing Nordic Clusters. Research Policy, 34(8), pp. 1173-90.

Asheim B. and Coenen L. (2006). Contextualising Regional Innovation Systems in a Globalising Learning Economy: On Knowledge Bases and Institutional Frameworks. Journal of Technology Transfer, 31(1), pp. 163-73. 
Asheim B. and Gertler M. S. (2005). The Geography of Innovation: Regional Innovation Systems. In: J. Fagerberg, D. S. Mowery and R. R. Nelson, eds., The Oxford Handbook of Innovation, Oxford New York: Oxford University Press, pp. 291-317.

Asheim B. and Isaksen A. (1997). Location, Agglomeration and Innovation: Towards Regional Innovation System in Norway?. European Planning Studies, 5(3), pp. 299-330.

Asheim B. and Isaksen A. (2002). Regional Innovation Systems: The Integration of Local 'Sticky' and Global 'Ubiquitous' Knowledge. Journal of Technology Transfer 27, pp. 77-86.

Asheim B. T., Boschma R. and Cooke P. (2011b). Constructing Regional Advantage: Platform Policies Based on Related Variety and Differentiated Knowledge Bases. Regional Studies, 45(7), pp. 893-904.

Asheim B., Coenen L., Moodysson J. and Vang J. (2007). Constructing Knowledge-based Regional Advantage: Implications for Regional Policy. Int. J. Entrepreneurship and Innovation Management, 7(2-), pp. 28-43.

Asheim B., Smith H. L. and Oughton C. (2011a). Regional Innovation Systems: Theory, Empirics and Policy. Regional Studies, 45(7), pp. 875-91.

Bathelt H. and Glückler J. (2014). Institutional Change in Economic Geography. Progress in Human Geography, 38(3), pp. 340-363.

Bathelt H., Malmberg A. and Maskell P. (2004). Clusters and Knowledge: Local Buzz, Global Pipelines and the Process of Knowledge Creation. Progress in Human Geography, 28(1), pp. 31-56.

Boschma R. (2005). Proximity and Innovation: A Critical Assessment. Regional Studies, 39(1), pp. 61-74.

Braczyk H., Cooke P. and Heidenreich M., eds., (1998). Regional Innovation Systems. London: UCL Press.

Cooke P. (2001). Regional Innovation Systems, Clusters, and the Knowledge Economy. Industrial and Corporate Change, 10(4), pp. 945-974.

Cooke P. (2004). Regional Innovation Systems - an Evolutionary Approach. In: P. Cooke, M. Heidenreich and H.-J. Braczyk, eds., Regional Innovation Systems: The Role of Governance in a Globalized World, London New York: Routledge, pp. 1-18.

Cooke P. and Propris L. D. (2011). A policy agenda for EU smart growth: the role of creative and cultural industries. Policy Studies, 32(4), pp. 365-75.

Cooke P., Roper S. and Wylie P. (2003). ‘The Golden Thread of Innovation' and Northern Ireland's Evolving Regional Innovation System. Regional Studies, 37(4), pp. 365-379

Cooke P., Uranga M. G. and Etxebarria G. (1997). Regional Innovation Systems: Institutional and Organizational Dimensions. Research Policy, 26(4-5), pp. 475-91. 
Crouch C., Schroder M. and Voelzkow H. (2009). Regional and Sectoral Varieties of Capitalism. Economy and Society, 38(4), pp. 654-78.

Doloreux D. and Parto S. (2005). Regional Innovation Systems: Current Discourse and Unresolved Issues. Technology in Society, 27(2), pp. 133-53.

Edquist C. (2005). Systems of Innovations: Perspectives and Challenges. In: J. Fagerberg, D. C. Mowery and R. R. Nelson, eds., The Oxford Handbook of Innovation, Oxford New York: Oxford University Press, pp. 181-208.

Etzkowitz H. and Leydesdorff L. (1997). Universities and the Global Knowledge Economy: A Tripple Helix of University-Industry-Government Relations. London: Pinter.

Farole T., Rodriguez-Pose A. and Storper M. (2011). Human Geography and the Institutions that Underlie Economic Growth. Progress in Human Geography, 35(1), pp. 58-80.

Florida R, Adler P., and Mellander C. (2017). The City as Innovation Machine. Regional Studies, 51(1), pp. 86-96.

Gertler M. S. (2004). Manufacturing Culture: The Institutional Geography of Industrial Practice. Oxford New York: Oxford University Press.

Gertler M. S. (2010). Rules of the Game: The Place of Institutions in Regional Economic Change. Regional Studies, 44(1), pp. 1-15.

Gertler M. S. and Wolfe D. A. (2002). Innovation and Social Learning: An Introduction. In: M. S. Gertler and D. A. Wolfe, eds., Innovation and Social Learning: Institutional Adaptation in an Era of Technological Change, New York: Palgrave Macmillan, pp. 1-24.

Grabher G. (1993). Rediscovering the social in the economics of interfirm relations. In: G. Grabher, ed., The Embedded Firm: On the Socioeconomic of Industrial Networks, London New York: Routledge, pp. 1-31.

Hall P. A. (2010). Historical Institutionalism in Rationalist and Sociological Perspective. In: J. Mahoney and K. Thelen, eds., Explaining Institutional Change: Ambiguity, Agency, and Power, Cambridge New York: Cambridge University Press, pp. 204-224.

Hall P. A. and Soskice D. (2001). An Introduction to Varieties of Capitalism. In: P. A. Hall and D. Soskice, eds., Varieties of Capitalism: The Institutional Foundations of Comparative Advantage, Oxford: Oxford University Press, pp. 1-70.

Hallencreutz D., Bjerkesjö P. and Daal C. (2008). Skånes regionala innovationssystem. En funktionsanalys. Region Skåne, Malmö.

Hassink R. (2010). Locked in Decline? On the Role of Regional Lock-ins in Old Industrial Areas. In: R. Boschma and R. Martin, eds., The Handbook of Evolutionary Economic Geography, Cheltenham: Edward Elger, pp. 450-70. 
Hodgson G. M. (1998). The Approach of Institutional Economics. Journal of Economic Literature, 36(1), pp. 166-92.

Iammarino S. (2005). An Evolutionary Integrated View of Regional Systems of Innovation: Concepts, Measures and Historical Perspectives. European Planning Studies, 13(4), pp. $497-$ 519.

Isaksen, A. and Trippl, M. (2016). Regional industrial path development in different types of regions: a conceptual analysis. In: D. Parrilli, R. Fitjar, A. Rodriguez-Pose, eds., Innovation drivers and regional innovation strategy, London: Routledge, pp. 66-84.

Johnson B. (2010). Institutional Learning. In: B.- $\AA$. Lundvall, ed., National Systems of Innovation: Toward a Theory of Innovation and Interactive Learning. London: Anthem Press

Lundvall B.-Å. (2010). Introduction. In: B.-Å. Lundvall, ed., National Systems of Innovation: Toward a Theory of Innovation and Interactive Learning, London/ New York: Anthem Press, pp. 1-19.

Martin R. (1994). Economic Theory and Human Geography. In: R. Martin and G. Smith, eds., Human Geography: Society, Space and Social Science, Basingstoke: Macmillan, pp. 21-53.

Martin R. and Moodysson J. (2013). Comparing Knowledge Bases: On the Geography and Organization of Knowledge Sourcing in the Regional Innovation System of Scania, Sweden. European Urban and Regional Studies, 20(2), pp. 170-187.

Miörner J., Zukauskaite E., Trippl M. and Moodysson J. (2017). Creating institutional preconditions for knowledge flows in cross-border regions. Environment in Planning C: Politics and Space, online first: doi/10.1177/2399654417704664

North D. (1990). Institutions, Institutional Change and Economic Performance. Cambridge: Cambridge University Press

Porter M. E. (1998). Clusters and the New Economics of Competition. Harvard Business Review, 76(6), pp. 77-90.

Scott A. J. (1998). Community, Local Democracy and Citizenship. Prospects, 28(2), pp. 32831 .

Scott W. R. (2008). Institutions and Organizations. London: Sage Publications

Scott W. R. (2010). Reflections: The Past and Future of Research on Institutions and Institutional Change. Journal of Change Management, 10(1), pp. 5-21.

Storper M. (1997). The Regional World. New York London: The Guilford Press

Storper M. and Scott A. J. (1995) The Wealth of Regions: Market Forces and Policy Imperatives in Local and Global Context. Futures, 27(5), pp. 505-526. 
Strambach S. (2010). Path Dependance and Path Plasticity: The Co-evolution of Institutions and Innovation - the German Customized Business Software Industry. In: R. Boschma and R. Martin, eds.,, The Handbook of Evolutionary Economic Geography, Cheltenham, Northampton, MA: Edward Elgar, pp. 406-431.

Trippl M., Asheim B. and Miörner J. (2016). Identification of regions with less-developed research and innovation systems. In: M. D. Parrilli, R. D. Fitjar \& A. Rodriguez-Pose, eds., Innovation Drivers and Regional Innovation Strategies, London: Routledge, pp. 23-44.

Tödtling F. and Trippl M. (2005). One Size Fits All? Towards a Differentiated Regional Innovation Policy Approach. Research Policy, 34(8), pp. 1203-1219.

Veblen T. (1898). Why is Economics not an Evolutionary Science?. The Quarterly Journal of Economics, 12(4), pp. 373-397.

Williamson O. E. (2000). The New Institutional Economics: Taking Stock, Looking Ahead. Journal of Economic Literature, 38(3), pp. 595-613.

Zukauskaite E. (2013). Institutions and the Geography of Innovation: A Regional Perspective. Lund: Lund University

Zukauskaite E. (2015). Organizational Change within Medical Research in Sweden: On the Role of Individuals and Institutions. Environment and Planning C: Government and Policy, 33(5), pp. 1190-1206

Zukauskaite, E., Trippl, M and Plechero, M (2017). Institutional Thickness Revisited, Economic Geography, 93(4), 325-346.

Table 1: Institutions and Spatial Dimension

\begin{tabular}{|l|l|l|}
\hline Type of Institutions & Examples & Main spatial dimension \\
\hline Regulative & $\begin{array}{l}\text { Laws, standards, sanctions: } \\
\text { national taxation policy, EU } \\
\text { regulation, international } \\
\text { agreements }\end{array}$ & Global and national \\
\hline Normative & $\begin{array}{l}\text { Values, social obligations, } \\
\text { expectations: trust, positive } \\
\text { attitudes towards learning and } \\
\text { innovation }\end{array}$ & Regional and global \\
\hline Cultural-cognitive & $\begin{array}{l}\text { Beliefs, views taken for granted: } \\
\text { shared understanding of the best } \\
\text { ways to organize activities }\end{array}$ & Regional and global \\
\hline
\end{tabular}

Source: Own elaboration based on SCOTT (2008: 51) 
Table 2: RIS Typologies and Institutional Characteristics

\begin{tabular}{|c|c|c|c|}
\hline Typology & Type of RIS & $\begin{array}{l}\text { Institutional } \\
\text { characteristics }\end{array}$ & Type of Institutions \\
\hline \multirow[t]{3}{*}{$\begin{array}{l}\text { Asheim and } \\
\text { Coenen }(2005) / \\
\text { Cooke }(2004)\end{array}$} & $\begin{array}{l}\text { Territorially } \\
\text { embedded/Localist-grassroots }\end{array}$ & $\begin{array}{l}\text { Geographical and } \\
\text { relational proximity } \\
\text { Well-developed relations } \\
\text { among SMEs and between } \\
\text { firms and policy makers }\end{array}$ & $\begin{array}{l}\text { Normative, cultural- } \\
\text { cognitive }\end{array}$ \\
\hline & $\begin{array}{l}\text { Regionalized } \\
\text { national/Globalized-dirigiste }\end{array}$ & $\begin{array}{l}\text { Central government } \\
\text { policies, central funding, } \\
\text { epistemic communities, } \\
\text { globally oriented networks }\end{array}$ & $\begin{array}{l}\text { Regulative, cultural- } \\
\text { cognitive }\end{array}$ \\
\hline & $\begin{array}{l}\text { Regionally } \\
\text { networked/Interactive- } \\
\text { networked RIS }\end{array}$ & $\begin{array}{l}\text { Regional institutional } \\
\text { infrastructure intentionally } \\
\text { strengthened } \\
\text { Well-developed networks } \\
\text { at different scales }\end{array}$ & Normative, regulative \\
\hline \multirow[t]{2}{*}{ Cooke (2004) } & IRIS & $\begin{array}{l}\text { Long-term interests of } \\
\text { shareholders, public } \\
\text { investment in innovation }\end{array}$ & Normative, regulative \\
\hline & ERIS & $\begin{array}{l}\text { Profit making interest of } \\
\text { shareholders }\end{array}$ & Normative \\
\hline \multirow[t]{3}{*}{$\begin{array}{l}\text { Tödtling and } \\
\text { Trippl (2005) }\end{array}$} & Locked-in RIS & $\begin{array}{l}\text { Functional, cognitive, } \\
\text { political lock-ins }\end{array}$ & Cultural-cognitive \\
\hline & Organizationally thin RIS & Thin institutional structure & $\begin{array}{l}\text { Normative, cultural- } \\
\text { cognitive }\end{array}$ \\
\hline & Fragmented RIS & Not mentioned & - \\
\hline
\end{tabular}

Source: Own summary 
Table 3: Institutions in Different Types of RIS

\begin{tabular}{|c|c|c|c|}
\hline $\begin{array}{l}\text { Typo- } \\
\text { logy }\end{array}$ & Type of RIS & Institutional framework: Elements and relations & Bottleneck \\
\hline \multirow[t]{3}{*}{$\begin{array}{l}\text { Asheim } \\
\text { and } \\
\text { Coenen } \\
(2005) / \\
\text { Cooke } \\
(2004)\end{array}$} & $\begin{array}{l}\text { Territorially } \\
\text { embedded / } \\
\text { Localist- } \\
\text { grassroots }\end{array}$ & $\begin{array}{l}\text { - Strong role of regional normative \& cognitive institutions } \\
\text { - Role of national institutions is limited to basic regulations } \\
\text { (e.g. labor regulation, tax policy) } \\
\text { - Weak role of global institutions } \\
\text { - Lack of interrelatedness }\end{array}$ & $\begin{array}{l}\text { Lack of } \\
\text { institutions for } \\
\text { supra-regional } \\
\text { collaboration }\end{array}$ \\
\hline & $\begin{array}{l}\text { Regionalized } \\
\text { national / } \\
\text { Globalized- } \\
\text { dirigiste }\end{array}$ & $\begin{array}{l}\text { - Strong role of cognitive \& normative institutions among } \\
\text { actors within the same industry/with the same educational } \\
\text { background (regional \& supra-regional) } \\
\text { - Weak regional institutions for collaboration across } \\
\text { industries/organizational fields } \\
\text { - Strong role of national regulative institutions predefining } \\
\text { support \& incentives structures for innovation } \\
\text { - Mainly complementary relations }\end{array}$ & $\begin{array}{l}\text { Lack of } \\
\text { institutions for } \\
\text { collaboration } \\
\text { across } \\
\text { industries/ } \\
\text { organizational } \\
\text { fields }\end{array}$ \\
\hline & $\begin{array}{l}\text { Regionally } \\
\text { networked/ } \\
\text { Interactive- } \\
\text { networked }\end{array}$ & $\begin{array}{l}\text { - Strong role of normative institutions supporting learning \& } \\
\text { knowledge exchange at regional \& supra-regional levels } \\
\text { - Strong role of regulative institutions (e.g. formal contracts } \\
\text { among regional actors) for knowledge exchange } \\
\text { - Strong role of national incentives structures supporting extra- } \\
\text { regional collaboration } \\
\text { - Strong role of global regulations: standards, agreements, IPR, } \\
\text { incentives structures for collaboration with distant partners } \\
\text { - Reinforcing and complementary }\end{array}$ & $\begin{array}{l}\text { Inappropriate or } \\
\text { lacking global } \\
\text { regulations }\end{array}$ \\
\hline \multirow[t]{2}{*}{$\begin{array}{l}\text { Cooke } \\
(2004)\end{array}$} & IRIS & $\begin{array}{l}\text { - Normative institutions at regional \& national levels promote } \\
\text { - } \text { High lerm interest and trust among stakeholders } \\
\text { - Typical CME regulty among employees and employers } \\
\text { - Basic global regulations: agreements, IPR, industry standards } \\
\text { - Mainly complementary relations }\end{array}$ & $\begin{array}{l}\text { Risk for } \\
\text { institutional } \\
\text { mismatch when } \\
\text { IRIS emerge in } \\
\text { LME type } \\
\text { country }\end{array}$ \\
\hline & ERIS & $\begin{array}{l}\text { - Normative institutions at regional \& national levels } \\
\text { encourage focus on profit and market demand } \\
\text { - Low loyalty between employers and employees } \\
\text { - Typical LME regulations at the national level } \\
\text { - Basic global regulations: agreements, IPR, industry standards } \\
\text { - Mainly complementary relations }\end{array}$ & $\begin{array}{l}\text { Risk of } \\
\text { institutional } \\
\text { mismatch when } \\
\text { ERIS emerge in } \\
\text { CME type } \\
\text { country }\end{array}$ \\
\hline \multirow[t]{3}{*}{$\begin{array}{l}\text { Tödtling } \\
\text { and } \\
\text { Trippl } \\
\text { (2005) }\end{array}$} & Locked-in RIS & $\begin{array}{l}\text { - Strong cognitive \& normative institutions at the regional } \\
\text { level define legitimate ways of behavior } \\
\text { - Work relations \& practices are clearly regulated at national } \\
\text { and global levels, presence of strong support structures } \\
\text { - Alternatively support structures can be terminated if the } \\
\text { regional industry declines } \\
\text { - Complementary or contradictory relations }\end{array}$ & $\begin{array}{l}\text { Lack of } \\
\text { institutions } \\
\text { supporting } \\
\text { renewal and } \\
\text { innovative ideas }\end{array}$ \\
\hline & $\begin{array}{l}\text { Organiza- } \\
\text { tionally thin } \\
\text { RIS }\end{array}$ & $\begin{array}{l}\text { - Lack of critical mass of actors needed to develop thick } \\
\text { normative \& cognitive institutions at the regional level } \\
\text { - Regulative institutions at national \& global levels that } \\
\text { address the issues of less developed regions } \\
\text { - Lack of interrelatedness }\end{array}$ & $\begin{array}{l}\text { Lack of } \\
\text { institutions } \\
\text { addressing the } \\
\text { issue of less } \\
\text { developed } \\
\text { regions }\end{array}$ \\
\hline & $\begin{array}{l}\text { Fragmented } \\
\text { RIS }\end{array}$ & $\begin{array}{l}\text { - Variety of different norms \& beliefs; varying level of trust } \\
\text { - Variety of different regulations (established rules \& support } \\
\text { structures for some industries; lacking or emerging ones for } \\
\text { other industries) } \\
\text { - Regulative institutions at national \& global levels supporting } \\
\text { collaboration among different stakeholders most relevant } \\
\text { - Complex relations: reinforcing, complementary, }\end{array}$ & $\begin{array}{l}\text { Contradicting } \\
\text { institutions } \\
\text { might hamper } \\
\text { innovation; } \\
\text { Lack of } \\
\text { institutions } \\
\text { supporting }\end{array}$ \\
\hline
\end{tabular}




\section{Source: Own draft}

\footnotetext{
i An example of this contingency as well as fluidity of institutions in the Swedish context is an institution of hand-shaking which has made a transition from a taken for granted behavior (cultural-cognitive element) to a morally governed activity (normative element), associated with norms regarding gender equality and tolerance. ${ }^{\text {ii }}$ We use Asheim and Coenen (2005), Cooke (2004) and Tödtling and Trippl (2005) as the main references when analyzing the typologies. However, we are aware that Asheim and Coenen (2005) and Cooke (2004) build upon previous work by Asheim and Isaksen (1997; 2002), Asheim (1998), Cooke (2001), Cooke et al. (2003) and Brazcyk et al. (1998).

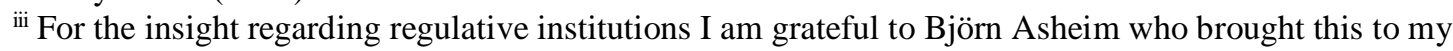
attention.
} 